Motivational dimension of willingness to communicate in L2: The impacts of criterion measure, ideal L2 self, family influence, and attitudes to L2 culture

Ghanizadeh, Afsaneh

Imam Reza International University, Mashhad, Iran (ghanizadeafsane@yahoo.com; a.ghanizadeh@imamreza.ac.ir)

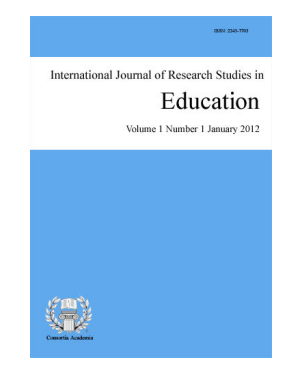

Eishabadi, Najmeh

Imam Reza International University, Mashhad, Iran (eishabadi.trading.co@gmail.com)

ISSN: 2243-7703 Online ISSN: 2243-7711

Rostami, Soroor

Imam Reza International University, Mashhad, Iran (rostami.soroor@yahoo.com)

OPEN ACCESS

\title{
Abstract
}

The purpose of the present study is to explore the interrelationship between four components of Dörnyei's Motivational Self-System (criterion measure, ideal L2 self, attitudes to L2 culture and community, and family influence) and willingness to communicate in the second language (L2 WTC). Questionnaire data were collected from 160 Iranian EFL learners. Results of multiple regression analysis indicated that four aforementioned motivational factors can account for approximately 10 percent of the variance in WTC among Iranian EFL learners. Furthermore, this study found that WTC correlated significantly and positively with all motivational factors except family influence. Besides, it was found that among the components of WTC, WTC in reading correlated with both criterion measure and ideal L2 self. WTC in writing did not correlate with any of the motivational factors. WTC in listening was associated with criterion measure as well as ideal L2 self, although the magnitude of correlation with ideal L2 self was higher. The discussion and implications of the findings are presented with reference to the earlier findings.

Keywords: L2 motivational self-system; criterion measure; ideal L2 self; attitudes to L2 culture and community; family influence; L2 WTC 


\section{Motivational dimension of willingness to communicate in L2: The impacts of criterion measure, ideal L2 self, family influence, and attitudes to L2 culture}

\section{Introduction}

For many decades, the term motivation has been underlined as a salient factor in second language acquisition research (SLA). It is undeniable that without motivation even those highly talented individuals are not able to gain long term goals (Dörnyei, 2005, p. 78). During the last few years many researchers have shown interest in the field of L2 motivation (e.g., Clement \& Gardner, 2001; Cohen \& Dörnyei, 2002; Dörnyei, 1998 , 1999a, 1999b, 2000, 2001a, 2001b, 2003; Dörnyei \& Skehan, 2003; MacIntyre, 2002). There has been an abundance of theory and models on the concept of motivation. According to Gardner`s theory of SLA motivation, integrative motivation is an important dimension of language learning which includes interest in foreign language, integrative orientation, attitude towards L2 community. He mentioned that those who were integratively motivated revealed more interest in L2 learning (Gardner, 1985).

From another point of view, motivation has been classified to two general types, namely intrinsic (own desire to learn L2) \& extrinsic motivation (for the sake of achieving good grade-finding suitable job) (Noels, Pelletier, Clement, \& Vallerand, 2000). According to Ushioda (2008), intrinsically motivated learners are likely to display much higher levels of involvement in L2 learning, and use a wider range of strategies. Researchers have always believed that L2 is something behind the ordinary communication and other variables might be noteworthy. In 2005, Dörnyei conceptualized L2 motivational self-system theory which was readily welcomed by L2 educationalists and researchers since it opened up an avenue for L2 motivational research. He built his theory on two paradigms, one L2 field and the other based on psychology. Concerning L2 field, we can refer to integrative motivation and the latter refers to the psychological research on the self. L2 motivational self-system comprises three dimensions:

$>\quad$ Ideal self, referring to L2 specific facet of one`s ideal self

$>$ Ought- to self ,referring to attributes that one believes one ought to possess in order to avoid possible negative outcomes

$>\quad$ L2 learning experience, which concerns situation-specific motives related to the immediate learning environment and experience

In effect, ideal self is the ideal image of the L2 user one wishes to be in the future. The ought-to L2 self refers to the attributes that one believes ought to possess as a result of various duties, requirements, or responsibilities in order to avoid possible negative outcomes (Dörnyei, 2005). In this framework, Ideal L2 self and Ought-to L2 self comprise the possible selves in the L2 Motivational Self System (Dörnyei, 2005, p.100). L2 learning experience refers to the situation-specific motives related to the immediate learning environment and experience (Dörnyei, 2005, p. 106). According to studies of Csizar and Kormos (2009), as well as that of Taguchi, Magid, and Papi (2009), this dimension of L2 Motivational Self System revealed the strongest impact on motivational behavior. For some language learners, as Dörnyei (2009) believed, successful engagement with actual language learning process is more important than internally or externally generated self-images.

Another factor which is note-worthy in accounting for L2 use revolves around the variables that constrain and enhance language learners' opportunities to use language to communicate, i.e., their willingness to communicate in L2 (L2 WTC). MacIntyre, Clément, Dörnyei, and Noels (1998) proposed the concept of WTC as a proper objective for second language education. Willingness to communicate was considered as an individual inclination actively entering into discourse at a particular time in specific situation (McCroskey \& Richmond, 1987). WTC was first presented as a fixed personality trait in L1 but when extended to L2 communication it was 
Motivational dimension of WTC in L2: The impacts of ideal L2 self, family influence, and attitudes to L2 culture purposed that many variables may influence WTC including personality, motivation, social situation, attitudes and many others (Macintyre, Clement, Dörnyei \& Noels, 1998).

\section{Review of Literature}

\subsection{L2 Moivational Self-System}

L2 motivation theories are highly influenced by Gardner's model of integrative motive as a motivational model called the socio-educational model (1985). This model was the supreme theory for explaining motivational dispositions of second language learners for some decades. It was originated from studies with a Canadian background (Gardner \& Lambert, 1972). The principles of the model stipulated that the sociocultural setting impacts learners' attitudes toward the target language and target community and culture. This referred to 'integrativeness' which is defined as having positive attitudes towards the target community and striving to integrate to that community. This view of motivation, however, went under attack by Dornyei (2005) who urged for the reinterpretation of the notion of intergrativeness. He noted that Gardner's theory of L2 motivation could not encompass the motivational disposition of learners who did not intend to integrate and assimilate to a partocular community but wished "integration with the global community rather than assimilation with native speakers" (p. 95). Consequently, research on motivation shifted to the 'situational' aspect of learning and focused instead on the immediate classroom situation.

This theoretical shift led to a groundbreaking conceptualization of motivation by Dörnyei: L2 Motivational Self System theory (2005). A distinguishing feature of this model lies in its dynamic representation of possible self-system. The concept of the possible self signifies an individual's conceptions of what they might become, what they would like to become and what they are afraid of becoming. In other words, possible selves envisage one's self in upcoming circumstances, such as thoughts, images, and feelings, and are the indicators of one's goals and desires. Markus and Ruvolo (1989) expressed that the emphasis on possible selves makes us "phenomenologically very close to the actual thoughts and feelings that individuals experience as they are in the process of motivated behavior and instrumental action" (p. 217, as cited in Dörnyei, 2005). Furthermore, as Dörnyei (2005) contended possible selves append freshness, vision, meaning, and purpose, to individuals' wishes and fears. The more vibrant and intricate the possible self, the more motivationally effective it would be.

The educational version of possible self can function as 'academic self-guide' and was coined as 'ideal self' by Higgins (1987, as cited in Dörnyei, 2005). It refers to the representation of characteristics one ideally likes to have (repertoires of wishes, objectives, and ambitions). The other side is called 'ought to self' and is the representation of the attributes that one believes one ought to possess (i.e. a representation of someone's sense of duty, assignments or responsibilities) and can virtually be detached from desires or wishes. According to this conceptualization of selves, motivation involves the wishes for people to reduce the incongruity between their actual and ideal/ought selves.

Notwithstanding the fact that ideal and ought selves converge in many respects, they diverge from each other when it comes to the motivation associated with future predictions. Ideal self has a promotion focus, having to do with wishes, ambitions, improvements, progress, and achievements; whereas ought to self has a prevention orientation, regulating one's activities, and is related to the protection, responsibilities, and commitments (Higgins, 1998).

Due to its comprehensiveness and vividness, Dörnyei's (2005) L2 Motivational Self System theory initiated lines of research in different EFL contexts. Taguchi, Magid, and Papi (2009) in their study in three important Asian contexts, Japan, China and Iran, verified the validity of the model and also reported certain cross-cultural differences in different educational contexts. One of remarkable cross-cultural differences pivoted around the influence of 'attitudes to L2 culture and community' and 'instrumentality-promotion' on the 'ideal L2 self'. In the Japanese model, the impact from 'attitudes to L2 culture and community' on the 'ideal L2 self' is 
nearly twice as large as from 'instrumentality-promotion', whereas in the Chinese and the Iranian data the contribution of the two aspects is roughly equal. Another discrepancy was detected in the 'ideal L2 self' to 'criterion measures' relationships. In China, 'attitudes to learning English' played a less central role than in Japan and Iran in influencing the amount of effort learners exerted on learning English.

Shahbaz and Liu (2012) conducted a study in Pakistan in a formal context to investigate the reasons of learning English for Pakistani students. The results showed that no single factor predicts L2 learning motivation for the target population. Language learning experience, international orientation, ideal L2 self and instrumentality all worked interconnected to motivate ESL learners. English as an international language had a strong influence on ESL learning for Pakistani learners with their colonial past. In the same year, Takahashi (2013) carried out an interview study to get a thorough understanding of the development of ideal L2 selves in a formal context in Japan. The results indicated that the interviewees' ideal L2 selves varied in terms of their contents and specifically exhibited some types of ideal L2 selves which were not included in many questionnaire studies.

\subsection{Willingness to Communicate in L2}

A number of studies demonstrated intertwining relationship between L2 WTC and other individual variables within the literature. These variables include motivation and attitudes (Hashimoto, 2002; MacIntyre, Baker, Clement, \& Donovan, 2003; Ryan, 2009), learner beliefs (Peng \& Woodrow, 2010) self-confidence (Clement, Baker, \& MacIntyre, 2003; Yashima, 2002), personality (Ghonsooly, Khajavi, \& Asadpour, 2012; MacIntyre \& Charos 1996; Mohammadian, 2013), and age and gender (MacIntyre, Baker, Clement, \& Donovan, 2002). Given that motivation is assumed to be a major affective variable influencing SLA, it has been accorded increasing research attention in recent years. A pyramid model of WTC was proposed by MacIntyre et al. (1998). This model proposes different potential influences on willingness to communicate in a second language. The fourth layer in the model is referred to as motivational propensities which can be conceptualized as stable individual difference traits and involves interpersonal motivation, intergroup motivation, and second language self-confidence. Each of these variables has been clearly associated with various L2 communication outcomes (MacDonald, Clément, \& MacIntyre, 2003). Motivation and integrativeness are considered as outstanding factors affecting learners' decision to cross their 'Rubicon' which is a metaphor for committing oneself to L2 communication (MacIntyre, 2007). Moreover, L2 WTC is viewed as an extension of the motivation construct (Dörnyei \& Skehan, 2003). Although the relationship between Motivation and L2 WTC is widely accepted, equivocal results have been yielded within the literature. For instance, some studies did not find any significant relationship between motivation and L2 WTC (Ghonsooly, Khajavi, \& Asadpour, 2012; MacIntyre \& Charos, 1996; Peng \& Woodrow, 2010), while this relationship is proved to be significant and positive in some studies conducted in different countries (Gardner, Smythe, Clément, \& Gliskman, 1976; Hashimoto, 2002; MacIntyre \& Clément, 1996; Peng, 2007, 2014).

Many early studies indicated the positive influence of motivation on L2 WTC. Gardner, Smythe, Clément, and Gliskman (1976) examined secondary school students in Canada by self-report questionnaires and found that the integrative motivation plays a role in the frequency of the L2 use. In a later study, MacIntyre and Clément (1996) examined the relationship among variables underlying WTC in a L2 and found a significant path between motivation and L2 WTC. Moreover, Hashimoto (2002) investigated affective variables as predictors of reported second language use in classrooms of Japanese students learning English as a Second Language. The study utilizing structural equation modeling indicated that the path from WTC to motivation was significant. In a similar way, Peng (2007) carried out a study among 174 college students attending an intensive English language program in China to examine the relationship between L2 WTC and integrative motivation. Using correlational analysis and multiple regression, the results indicated that motivation was the strongest predictor of L2 WTC. Yu (2009) replicated the study conducted by Peng (2007) using path model and the same results were obtained. In a recent study, Peng (2014) for the first time conducted a study to explore the interrelationships between the three components of second language motivational self-system (i.e., ideal L2 self, ought-to L2 self, and L2 learning 
Motivational dimension of WTC in L2: The impacts of ideal L2 self, family influence, and attitudes to L2 culture experience), international posture, L2 anxiety, and willingness to communicate (WTC) using structural equation modeling. The data were gathered from 1,013 university students in China. The results indicated that L2 WTC inside the classroom was influenced by L2 anxiety and L2 learning experience directly. He also found that ideal L2 self and ought-to L2 self, respectively, has a negative and positive effect on L2 anxiety and in turn L2 anxiety has a negative effect on in-class L2WTC.

Although many studies have indicated the positive influence of motivation on L2 WTC, a number of studies revealed confounding results. MacIntyre and Charos (1996) inferred a path leading from L2 WTC to motivation using path analysis. This expected path was eventually not statistically supported. In an attempt to examine relationships among L2 learning and L2 communication variables in the Japanese English as a foreign language context, Yashima (2002) found that motivation did not affect willingness to communicate in a second language directly. The same results were obtained by Peng and Woodrow's study (2010). They tested a hypothesized model integrating WTC in English, communication confidence, learner beliefs, motivation, and classroom environment utilizing structural equation modeling. The results indicated that motivation influences communication confidence but did not affect WTC directly. These inconsistent findings may be related to different contextual variables involved and varying statistical techniques employed, which mandate further empirical research. The present study is a further attempt to probe into L2 WTC in an EFL context and see whether and to what degree it is influenced by motivational factors (criterion measure ideal L2 self, attitudes to L2 culture and community, and family influence).

\section{Methodology}

\subsection{Participants}

A total of 160 male and female students took part in this study. The study was conducted in a foreign language institute in Iran. Virtually, all participants had quiet the same English background and were studying English at intermediate level. Their age ranged from 14 to 21 with the average of 17.

\subsection{Instruments}

Motivation Questionnaire - Out of 10 sub-factors of Dörnyei's L2 Motivational Self System questionnaire, 4 factors were employed to inform the present research. These factors include criterion measure, ideal L2 self, family influence, attitudes to L2 community on a 6 point Likert scale ranging from strongly disagrees to strongly agree. In the followings, each of these factors along with sample items is represented (Taguchi, Magid, \& Papi, 2009):

$>$ Criterion measure assesses the learners' intended efforts toward learning English (e.g., I would like to spend lots of time studying English, \& I would like to concentrate on studying English more than any other topic). The reliability of this subscale (computed via Cronbach's alpha) in the original study was found to be 0.79 and in this study it was .0 .72 .

Ideal L2 self refers to the "L2-specific facet of one's ideal self: If the person we would like to become speaks an L2, the Ideal L2 Self is a powerful motivator to learn the L2 because of the desire to reduce the discrepancy between our actual and ideal selves" (Dörnyei, 2005, p. 105). (e.g., I can imagine myself living abroad and using English effectively for communicating with the locals and I can imagine myself speaking English with international friends or colleagues). The reliability of this subscale in the original study was found to be 0.79 and in this study it was .0 .81 .

> Attitudes to L2culture and community investigating the learner's attitudes toward the community of the target language (e.g., Do you like meeting people from English-speaking countries? and Would you like to know more about people from English-speaking countries?). The reliability of this subscale in 
the original study was found to be 0.79 and in this study it was .0 .71 .

$>\quad$ Family influence examining active and passive parental roles (e.g. My parents/family believes that I must study English to be an educated person \& Studying English is important to me in order to bring honors to my family). The reliability of this subscale in the original study was found to be 0.69 and in this study it was .0.61.

WTC in English inside the classroom - L2 WTC was measured with the WTC scale designed by Peng and Woodrow (2010). It was adapted from MacIntyre, Baker, Clément, and Conrod (2001). The scale operationalizes L2 WTC in four basic skill areas (listening, speaking, reading, and writing), measuring students' willingness to engage in L2 communication inside and outside the classroom. The 'Inside the Classroom Scale' was adapted slightly to include communication tasks more common to the EFL class. 27 items adapted from MacIntyre, Baker, Clément, and Conrod (2001) assessed the frequency of time that students would choose during which to communicate in English in their classroom. Responses to the items on a 5-point Likert scale were anchored at one end by "Almost never willing" and at the other end by "Almost always willing". Higher scores indicate higher levels of WTC in English. The respondents are asked to indicate the frequency of time they choose to communicate in English in each classroom situation. Items 1-8 measure 'speaking' module, items 9-14 assess 'reading' dimension, items 15-22 concern 'writing' aspect, and items 23 - measure 'listening' facet. The reliability of the scale in the original study was found to be (.92) and in the present study, it was (.83).

\subsection{Procedure}

The survey was administered in EFL Iranyar institution in Iran. It took approximately 20 minutes for students to answer the questionnaires. All of the students voluntarily participated in this research. Prior to responding, a brief explanation was given on account of the aim of study and the format of questionnaire. After gathering the papers, the data were coded with the help of SPSS software.

\section{Results}

Table 1 represents the descriptive statistics of WTC and its comprising factors (speaking, reading, writing, and listening).

Table 1

Descriptive Statistics of WTC in L2 and its Comprising Factors

\begin{tabular}{lccccc}
\hline & $\mathrm{N}$ & Minimum & Maximum & Mean & Std. Deviation \\
\hline WTC in Speaking & 160 & 8.00 & 38.00 & 26.04 & 5.60 \\
WTC in Reading & 160 & 6.00 & 30.00 & 20.44 & 4.87 \\
WTC in Writing & 160 & 8.00 & 40.00 & 25.40 & 5.82 \\
WTC in Listening & 160 & 5.00 & 25.00 & 16.64 & 3.73 \\
WTC in L2 & 160 & 27.00 & 123.00 & 88.53 & 15.92 \\
Valid N (list wise) & 160 & & & & \\
\hline
\end{tabular}

Table 2 presents descriptive statistics of EFL learners' criterion measure, ideal L2 self, family influence, and attitudes to L2 culture and community.

Table 2

Descriptive of Criterion Measure, Ideal L2 Self, Family Influence, \& Attitudes to L2 Culture \& Community

\begin{tabular}{lccccc}
\hline & $\mathrm{N}$ & Minimum & Maximum & Mean & Std. Deviation \\
\hline Criterion measure & 160 & 6.00 & 36.00 & 28.17 & 6.29 \\
Ideal L2 self & 160 & 6.00 & 36.00 & 28.62 & 6.23 \\
Family influence & 160 & 6.00 & 36.00 & 23.09 & 6.68 \\
Attitudes to L2 culture & 160 & 7.00 & 42.00 & 32.69 & 6.40 \\
Valid N (list wise) & 160 & & & & \\
\hline
\end{tabular}


To investigate the relationship between EFL learners' WTC in L2 and the motivational factors, a Pearson Product-Moment correlation was employed. The results are displayed in Table 3. As it can be seen, WTC correlated significantly and positively with criterion measure $(r=.261, p<.05)$, ideal L2 self $(r=.311, p<.05)$, and attitudes to L2 culture and community $(r=.239, p<.05)$. On the other hand, it was found that WTC is not associated with family influence $(r=.062, p<.05)$.

\section{Table 3}

The Correlation Coefficients between WTC and Motivation

\begin{tabular}{lc}
\hline & WTC in L2 \\
\hline 1. Criterion measure & $.261^{* *}$ \\
2. Ideal L2 self & $.311^{* *}$ \\
3. Family influence & .062 \\
4. Attitudes to L2 culture & $.239^{* *}$ \\
\hline Note. ${ }^{* *}$ Correlation is significant at the level of 0.05 &
\end{tabular}

To examine the association between the correlated motivational factors and the subcomponents of WTC (speaking, reading, writing, and listening) multiple correlations were applied to the data. The results are displayed in Table 4.

\section{Table 4}

The Correlation between Motivation and Subscales of WTC

\begin{tabular}{llllllll}
\hline \multicolumn{1}{l}{ 1. Criterion measure } & 1 & 2 & 3 & 4 & 5 & 6 & 7 \\
2. Ideal L2 self & 1.00 & & & & & & \\
3. Attitudes to L2 culture & $.686^{* *}$ & 1.00 & & & & & \\
4. WTC in speaking & $.441^{* *}$ & $.534^{* *}$ & 1.00 & & & & \\
5. WTC in reading & $.212^{* *}$ & $.256^{* *}$ & $.327^{* *}$ & 1.00 & & & \\
6. WTC in writing & $.247^{* *}$ & $.282^{* *}$ & .192 & $.468^{* *}$ & 1.00 & & \\
7. WTC in listening & .148 & $.156^{*}$ & .103 & $.517^{* *}$ & $.574^{* *}$ & 1.00 & \\
\hline
\end{tabular}

As Table 4 indicates, WTC in speaking is associated with the three motivational factors with the highest correlation with attitudes to L2 culture $(r=.327, p<.05)$. WTC in reading correlates with both criterion measure $(r=.212, p<.05)$ and ideal L2 self $(r=.282, p<.05)$. WTC in writing does not correlate with any of the motivational factors. WTC in listening is associated with criterion measure $(r=.241, p<.05)$ as well as ideal L2 self $(r=.332, p<.05)$, although the magnitude of correlation with ideal L2 self is higher. In sum, among the components of WTC, criterion measure has the highest correlation with reading $(r=.247, p<.05)$. Ideal L2 self has the highest correlation with listening $(r=.332, p<.05)$. Attitudes to L2 culture has the highest correlation with speaking $(r=.327, p<.05)$.

To see what percentage of variability in WTC can be accounted for by taking into consideration motivational factors (criterion measure, ideal L2 self, and attitudes), a regression analysis was employed. The following Table (Table 5) is the ANOVA table of regression for WTC and the aforementioned motivational factors. The magnitude of $F$-value $(F=5.125)$ and the amount of the respective $p$-value $(p<0.05)$ indicate the considered model is significant.

\section{Table 5}

The ANOVA Table of Regression for WTC and Motivation

\begin{tabular}{llccccc}
\hline & Model & Sum of Squares & df & Mean Square & F & Sig. \\
\hline \multirow{2}{*}{1} & Regression & 4706.322 & 4 & 1176.581 & 5.125 & $.001^{\mathrm{b}}$ \\
& Residual & 35585.578 & 155 & 229.584 & & \\
\multicolumn{2}{l}{ Tote. a. Dependent Variable: WTC. b. Predictors: (Constant), criterion } & & & & \\
\hline
\end{tabular}


Ghanizadeh, A., Eishabadi, N., \& Rostami, S.

According to Table 6, ideal L2 self and attitudes to L2 culture are positive predictors of the dependent variable, i.e., WTC. This can be figured out by examining the magnitude of the $t$-value (which should be higher than the critical level) and the $p$-value (which should be less than the significance level, i.e., 0.05). To check which one has more predictive power the magnitude of $B$ should be examined. Hence, here ideal L2 self has the highest predictive power.

Table 6

The Results of Regression Analysis Motivation and WTC

\begin{tabular}{|c|c|c|c|c|c|}
\hline \multirow{2}{*}{ Model } & \multicolumn{2}{|c|}{ Unstandardized Coefficients } & \multirow{2}{*}{$\begin{array}{c}\text { Standardized Coefficients } \\
\text { Beta }\end{array}$} & \multirow{2}{*}{$\mathrm{t}$} & \multirow{2}{*}{ Sig. } \\
\hline & B & Std. Error & & & \\
\hline (Constant) & 62.063 & 7.159 & & 8.669 & .000 \\
\hline Criterion measure & .250 & .268 & .099 & 930 & .354 \\
\hline Ideal L2 self & .608 & .289 & .238 & 2.103 & .037 \\
\hline Family influence & .263 & .203 & .110 & .294 & .197 \\
\hline Attitudes & .504 & .224 & .099 & 2.004 & .049 \\
\hline
\end{tabular}

Note. a. dependent variable: WTC

Table 7 is the $\mathrm{R}$ square table. As it can be seen, the model containing four motivational factors (criterion measure, ideal L2 self, family influence, and attitudes) can account for about 10 percent of variability in WTC.

Table 7

$R$ Square Table for Motivational Factors as the Predictors of WTC

\begin{tabular}{lcccc}
\hline Model & $\mathrm{R}$ & $\mathrm{R}$ Square & Adjusted R Square & Std. Error of the Estimate \\
\hline 1 & $.342^{\mathrm{a}}$ & .117 & .104 & 15.15 \\
\hline Note. a. Predictors: (Constant), criterion measure, ideal L2 self, family influence, and attitudes
\end{tabular}

\section{Discussion}

The present study demonstrated that four aforementioned motivational factors can account for approximately 10 percent of the variance in WTC among Iranian EFL learners. In other words, motivation predicts the student's willingness to communicate in English directly. This finding can be explained with reference to Dörnyei and Skehan (2003) who viewed second language willingness to communicate as an extension of the motivation construct. This finding is in line with the previous empirical studies across different contexts in Canada, Japan, and China (Gliksman, Gardner, \& Smythe, 1982; Hashimoto, 2002; MacIntyre \& Clément, 1996; Peng, 2007, 2014). Gliksman, Gardner, and Smythe (1982) found that integratively motivated students took every opportunity to perfect their second-language skills, and viewed the classroom as an opportunity to use their L2. The results of Hashimoto's (2002) study also revealed that students who had greater motivation for language learning and were more willing to communicate reported using the language more frequently in the classroom. Moreover, Peng (2014) found that students with strong ideal L2 selves were likely to align their aspirations to L2-related attributes expected in L2 use situations, which reduced their anxiety arousal. This reduction in L2 anxiety level of students indirectly influenced L2 WTC.

This study found that WTC correlated significantly and positively with criterion measure. Criterion measure assesses the learners' intended efforts toward learning English; in other words, it seeks to find to what extent learners like to spend time studying English. So, it seems conceivable that learners who want to exert ample effort in learning English are more willing to communicate and use the second language in the classroom.

The results also revealed that the relationship between WTC and ideal L2 self was significant and positive. The concept of the ideal L2 self has the potential to overcome the distinction between instrumentality and integrativeness (Gardner, 1985). The ideal or hoped-for self is the image L2 learners would very much like to become and may envisage themselves of being a person competent in the L2. Moreover, Dörnyei (2009) asserted that ideal L2 self has a promotion focus and learners with strong ideal L2 selves are likely to align their aspirations to L2-related attributes expected in L2 use situations. The results are consistent with the study 
Motivational dimension of WTC in L2: The impacts of ideal L2 self, family influence, and attitudes to L2 culture conducted by Peng (2014) who found that Ideal L2 self exerted a negative effect on L2 anxiety and indirectly predicted WTC.

Furthermore, significant positive correlation was obtained between WTC and attitudes to L2 culture and community. This motivational factor measures the learner's attitudes towards the target community and its culture. In Iran as a foreign language learning setting, outside of the classroom learners have very few opportunities to use the target language and have limited exposure to English-speaking culture, most often through a distorted lens like movie or music. So, it is quite reasonable that EFL learners who are more motivated to travel to English-speaking counties and become familiar with their culture, view the classroom as the only chance (opportunity) to use the foreign language.

On the other hand, it was found that family influence was not associated with WTC. Family influence involves active and passive parental roles. In other words, it delineates the extent families believe that their children must study English to be an educated person and to bring honors to the family. It was indicated that this motivational factor had no significant impact on Iranian students' WTC. This is probably due to the rise of individualism among Iranians. Individualism is the idea that the person makes his choices by seeing how the value impacts his life and freedom of thought and action for each person is the most important issue.

Among the components of WTC, criterion measure had the highest correlation with reading. Through reading as a receptive skill, learners receive information. Inasmuch as criterion measure assesses learners' intended efforts to learn language, reading helps them to achieve their academic goals. Accordingly, it seems plausible that by reading more extensively they can learn better.

Besides, it was demonstrated that ideal L2 self had the highest correlation with listening. According to Saricoban (1999), listening is one of the fundamental language skills through which learners gain a large portion of their education, information, understanding of the world, and their ideals. It well requires imagination, attention, thought, and interpretation. Hence, by listening skill learners can visualize and make optimal use of their imagination thereby manifesting Ideal L2 self.

Ultimately, attitudes to L2 culture showed the highest correlation with speaking. According to Samovar and Porter (1985), culture shapes human communication behavior; hence, cultural inhibition creates a defensive status to talk. For that reason, the amount of talking in which Iranian EFL learners engage would be dependent, at least in part, on how much they know about the culture of target language and how interested they are in cultural themes.

\section{Conclusions}

Derived from Dôrnyei's L2 motivational self-system, the present research probed a number of pivotal sub-factors of Dôrnyei's model pertain to language use in EFL classes. In effect, the findings demonstrated almost all motivational variables under study (EFL learners' criterion measure, ideal L2 self, family influence, and attitudes to L2 culture and community) stimulated language learners to strive for effective language learning through willingness to communicate in the classroom setting. In particular, it was found that the facilitative role of ideal L2-self prevailed other factors. This highlights the promotion orientation of ideal L2 self having to do with wishes, ambitions, improvements, progress, and achievements. In other words, it appears without possessing a vivid and elaborate vision of what we would like to do with L2 and which kind of L2 speaker we strive for, it is hardly possible to use language in L2 classroom effectively and enthusiastically. This is in line with the statement articulated earlier: ideal self brings about freshness, vision, meaning, and purpose, to individuals' wishes and uncertainties. The more vibrant and intricate the possible self, the more motivationally effective it would be.

The present study puts forward a number of implications for teachers and parents. Due to lack of L2 communication in Iran as an EFL context, and the increasing need for communicating with the global 
Ghanizadeh, A., Eishabadi, N., \& Rostami, S.

community, attempts to promote learners' WTC is an indispensable task of L2 educational scheme. Accordingly, language educators and parents play a key role in leading learners toward an awareness of their participation in the global community and the notion of ideal L2 selves. With regards to the positive impact of motivation on the learners' L2 WTC, providing an exciting and stimulating classroom environment to introduce culture and community of target language would be effective in increasing willingness to communicate and use of L2 in classroom. This is in accordance with previous research on environmental perceptions of classroom activities. In a recent study, Ghanizadeh and Jahedizadeh (2015) reported that EFL students who displayed higher interest in their classes were more motivated towards attaining intrapersonal competence and ultimately achieved higher academic gains. In addition, findings revealed the positive correlation between L2 WTC and criterion measures. In other words, when the decision to communicate emanates from oneself, further gains in L2 WTC would result. Hence, utilizing authentic L2 communication, may lead students to more language use. In conclusion, a better understanding of the effect of motivation on L2 WTC may help language educators to improve their curriculum design to offer more incentive opportunities for language learners and abet actual communication.

\section{References}

Brander, A. (2013). Developing language learners with Dörnyei: A study of learning environments and motivation at a Swedish upper-secondary school. Unpublished Masteral Thesis, University of Högskolan, Sweden.

Clément, R., Baker, S. C., \& MacIntyre, P. D. (2003). Willingness to communicate in a second language: The effects of context, norms, and vitality. Journal of Language and Social Psychology, 22(2), 190-209. http://dx.doi.org/10.1177/0261927X03022002003

Clément, R., \& Gardner, R. C. (2001). Second language mastery. In H. Giles \& W. P. Robinson (Eds.), The new handbook of language and social psychology (2nd ed.). London: Wiley.

Cohen, A. D., \& Dörnyei, Z. (2002). Focus on the language learner: Motivation, styles, and strategies. In N. Schmitt (Ed.), An introduction to applied linguistics (pp. 170-190). London: Arnold.

Csizér, K., \& Kormos, J. (2009). Learning experiences, selves and motivated learning behaviour: A comparative analysis of structural models for Hungarian secondary and university learners of English. In Z. Dörnyei \& E. Ushioda (Eds.), Motivation, language identity and the L2 self (pp. 98-119). Clevedon, UK.

Dörnyei, Z. (1998). Motivation in second and foreign language learning. Language Teaching, 78, 117-135. http://dx.doi.org/10.1017/S026144480001315X

Dörnyei, Z. (1999a). Motivation. In J. Verschueren, J.Ostmann, J. Blommaert, \& C. Bulcaen (Eds.), Handbook of pragmatics (pp. 1-22). Amsterdam: John Benjamins.

Dörnyei, Z. (1999b). Motivation. In B. Spolsky (Ed.), Concise encyclopedia of educational linguistics (pp. 525-532). Oxford: Pergamon.

Dörnyei, Z. (2000). Motivation. In M. Byram (Ed.), Routledge encyclopedia of language teaching and learning (pp. 425-432). London: Routledge.

Dörnyei, Z. (2001a). New themes and approaches in second language motivation research. Annual Review of Applied Linguistics, 21, 43-59. http://dx.doi.org/10.1017/S0267190501000034

Dörnyei, Z. (2001b). Teaching and researching motivation. Harlow: Longman.

Dörnyei, Z. (2003). Attitudes, orientations, and motivations in language learning: Advances in theory, research, and applications. In Z. Dörnyei (Ed.), Attitudes, orientations, and motivations in language learning (pp. 3-32). Oxford: Blackwell. http://dx.doi.org/10.1111/1467-9922.53222

Dörnyei, Z. (2005). The psychology of the language learner: Individual differences in second language acquisition. Mahwah, NJ: Lawrence Erlbaum.

Dörnyei, Z. (2009). The L2 motivational self system. In Z. Dörnyei \& E. Ushioda (Eds.). Motivation, language identity and the L2 self (pp. 9-42). Bristol: Multilingual Matters.

Dörnyei, Z., \& Skehan, P. (2003). Individual differences in second language learning. In C. J. Doughty, \& M. H. Long (Eds.), The handbook of second language acquisition (pp. 589-630). Oxford: Blackwell. http://dx.doi.org/10.1002/9780470756492.ch18 
Motivational dimension of WTC in L2: The impacts of ideal L2 self, family influence, and attitudes to L2 culture

Gardner, R.C. (1985). Social psychology and second language learning: The role of attitudes and motivation, London: Edward Arnold.

Gardner, R. C., \& Lambert, W. E. (1972). Attitudes and motivation in second language learning. Rowley, Massachusetts: Newbury House Publishers.

Gardner, R. C., Smythe, P. C., Clément, R., \& Gliskman, L. (1976). Second-language learning: A social psychological perspective. The Canadian Modern Language Review, 32, 198-213.

Ghanizadeh, A., \& Jahedizadeh, S. (2015). An exploration of EFL learners' perceptions of classroom activities and their achievement goal orientations. International Journal of Research Studies in Education, 4(3), 33-45. http://dx.doi.org/10.5861/ijrse.2015.1032

Ghonsooly, B., Khajavy, G. H., \& Asadpour, S. F. (2012). Willingness to communicate in English among Iranian non-English major university students. Journal of Language and Social Psychology, 31(2), 197-211. http://dx.doi.org/10.1177/0261927X12438538

Gliksman, L., Gardner, R. C., \& Smythe, P. C. (1982). The role of the integrative motive on students' participation in the French classroom. The Canadian Modern Language Review, 38, 625-647.

Hashimoto, Y. (2002). Motivation and willingness to communicate as predictors of reported L2 use: The Japanese ESL context. Second Language Studies, 20(2), 29-70.

Higgins, E. T. (1987). Self-discrepancy: A theory relating self and affect. Psychological Review, 94(3), 319-340. http://dx.doi.org/10.1037/0033-295X.94.3.319

Higgins, E.T. (1998). Promotion and prevention: Regulatory focus as a motivational principle. Advances in Experimental Social Psychology, 30, 1-46. http://dx.doi.org/10.1016/S0065-2601(08)60381-0

MacDonald, J. R., Clément, R., \& MacIntyre, P.D (2003). Willingness to communicate in a L2 in a bilingual context: A qualitative Investigation of Anglophone and Francophone students. Unpublished Manuscript. Retrieved from http://faculty.cbu.ca/pmacintyre/research_pages/publications.htm

MacIntyre, P. D. (2002). Motivation, anxiety and emotion in second language acquisition. In P. Robinson (Ed.), Individual differences in second language acquisition (pp. 45-68). Amsterdam: John Benjamins. http://dx.doi.org/10.1075/11lt.2.05mac

MacIntyre, P. D. (2007). Willingness to communicate in the second language: Understanding the decision to speak as a volitional process. The Modern Language Journal, 91(4), 564-576. http://dx.doi.org/10.1111/j.1540-4781.2007.00623.x

MacIntyre, P. D., Baker, S. C., Clément, R., \& Donovan, L. A. (2002). Sex and age effects on willingness to communicate, anxiety, perceived competence, and L2 motivation among junior high school French immersion students. Language Learning, 52(3), 537-564. http://dx.doi.org/10.1111/1467-9922.00194

MacIntyre, P. D., Baker, S. C., Clément, R., \& Donovan, L. A. (2003). Talking in order to learn: Willingness to communicate and intensive language programs. Canadian Modern Language Review, 59(4), 589-607. http://dx.doi.org/10.3138/cmlr.59.4.589

MacIntyre, P. D., \& Charos, C. (1996). Personality, attitudes, and affect as predictors of second language communication. Journal of Language and Social Psychology, 15(1), 3-26. http://dx.doi.org/10.1177/0261927X960151001

MacIntyre, P. D., \& Clément, R. (1996, August). A model of willingness to communicate in a second language: The concept, its antecedents and implications. Paper presented at the World Congress of Applied Linguistics (AILA), Jyväskylä, Finland.

MacIntyre, P. D., Clément, R., Dörnyei, Z., \& Noels, K. A. (1998). Conceptualizing willingness to communicate in a L2: A situational model of L2 confidence and affiliation. Modern Language Journal, 82, 545-562. http://dx.doi.org/10.1111/j.1540-4781.1998.tb05543.x

Markus, H., \& Ruvolo, A. (1989). Possible selves: Personalized representations of goals. In L. A. Pervin (Ed.), Goal concepts in personality and social psychology (pp. 211-241). Hillsdale, NJ: Lawrence Erlbaum Associates.

McCroskey, J. C., \& Richmond, V. P. (1987). Willingness to communicate. In J. C. McCroskey \& J. A. Daly (Eds.), Personality and interpersonal communication (pp. 129-156). Newbury Park, CA: Sage.

Mohammadian, T. (2013). The effect of shyness on Iranian EFL learners' language learning motivation and 
Ghanizadeh, A., Eishabadi, N., \& Rostami, S.

willingness to communicate. Theory and Practice in Language Studies, 3(11), 2036-2045. http://dx.doi.org/10.4304/tpls.3.11.2036-2045

Noels, K. A., Pelletier, L. G., Clément, R., \& Vallerand, R. J. (2000). Why are you learning a second language? Motivational orientations and self-determination theory. Language Learning, 50, 57-85. http://dx.doi.org/10.1111/0023-8333.00111

Peng, J. (2007). Willingness to communicate in an L2 and integrative motivation among college students in an intensive English language program in China. University of Sydney Papers in TESOL, 2, 33-59.

Peng, J. (2014). L2 motivational self-system, attitudes, and affect as predictors of 12 WTC: An imagined community perspective, The Asia-Pacific Education Researcher, 24(2), 433-443. http://dx.doi.org/10.1007/s40299-014-0195-0

Peng, J., \& Woodrow, L. J. (2010). Willingness to communicate in English: A model in Chinese EFL classroom context. Language Learning, 60(4), 834-876. http://dx.doi.org/10.1111/j.1467-9922.2010.00576.x

Ryan, S. (2009). Self and identity in L2 motivation in Japan: The ideal L2 self and Japanese learners of English. In Z. Dörnyei \& E. Ushioda (Eds.), Motivation, language identity and the L2 self (pp. 120-143). Bristol: Multilingual Matters.

Samovar, L. A., \& Porter, R. E. (Eds.) (1985). Intercultural communication: A Reader. Belmont, CA: Wadsworth.

Saricoban, A. (1999). The teaching of listening. The Internet TESL Journal, 5(12). Retrieved from http://iteslj.org/Articles/Saricoban-Listening.html

Shahbaz, M., \& Liu, Y. (2012). Complexity of L2 motivation in an Asian ESL setting. Porta Linguarum, 18, 115-131.

Taguchi, T., Magid, M., \& Papi, M. (2009). The L2 motivational self-system among Japanese, Chinese, and Iranian learners of English: A comparative study. In Z. Dörnyei \& E. Ushioda (Eds.), Motivation, language identity and the L2 self (pp. 66-97). Clevedon, UK: Multilingual Matters.

Takahashi, C. K. (2013). Ideal L2 self and university English learners: An interview study. The Language Teacher, 37 (6), 3-8.

Ushioda, E. (2008). Motivation and good language learners. In C. Griffiths (Ed.), Lessons from Good Language Learners (pp. 19-34). Cambridge: Cambridge University Press. http://dx.doi.org/10.1017/CBO9780511497667.004

Yashima, T. (2002). Willingness to communicate in a second language: The Japanese EFL context. The Modern Language Journal, 86(1), 54-66. http://dx.doi.org/10.1111/1540-4781.00136

Yu, M. (2009). Willingness to communicate of foreign language learners in a Chinese setting. Unpublished doctoral dissertation, Florida State University. 